\title{
A Risk Communication Strategy to Support Implementation Child Rights Protection Program: A Descriptive Qualitative Study in ALIT Indonesia Foundation during the COVID- 19 Pandemic
}

\author{
Amalia Fibrianty ${ }^{1}$, Rachmat Kriyantono ${ }^{2}$, Maulina Pia Wulandari ${ }^{3}$ \\ 1,2,3Universitas Brawijaya, Malang Indonesia \\ Email: amalia.fibrianty@gmail.com
}

\begin{abstract}
During the pandemic COVID-19, the number of Child Rights violations have been increased such as sexual harassment, the exploitation of the children, and child abuse. Moreover, during the regulation such as "lockdown" that forced people to stay at home has been putting the children into another risks. Thus, it is important for Civil Society Organization (CSO) who works with the children to have its risk communication strategy in its Child Rights Protection (CRP) program implementation. This study is to address the risk communication and community engagement (RCCE) strategy in supporting the sustainability of CRP program implementation in ALIT Indonesia Foundation during pandemic COVID-19. The writer assumed that the organization has been applied a good strategy for its risk management. Moreover, using a descriptive qualitative research methods and data gathering from interview and literature review, it founds that the risk communication strategy adjustment applied by ALIT Indonesia Foundation on its CRP program implementation not only helped the organization in working with the children and their family as the target group, but also giving advocacy about the Child Rights to the stakeholders during pandemic COVID-19. The organization run some strategies based on the government's health protocols during pandemic, such as physical distancing, wearing mask, hand washing. They also use social media such as Zoom, WhatsApp, Facebook, Instagram and YouTube to outreach their target group who live in the internet-accessible area, but for those who are living in the remote area, they had field staffs as the interconnector to their volunteer in the field, and spread the key messages of the CRP program through local radio station, or they gather the children of 4 who live nearby to disseminate the information.
\end{abstract}

Keywords: Crisis Communication, Risk Management, Communication Risk, CSO, Child Rights Protection (CRP), Program Implementation.

\section{A. INTRODUCTION}

The pandemic COVID-19 has broadly giving impacts to children as one of the vulnerable group (Hazarika \& Dutta, 2020; SS Teo, S., \& Griffiths, G., 2020). The number of Children violation in Indonesia is significantly increased during the pandemic such as child abuse and neglect, domestic violence, online gender based violence (KBGO), sexual harassment, violation in relationship, child poverty which drives into child trafficking and sexual exploitation of the children, and child marriage (Kendedes, I., 2020; National Commission Violation against Women, 2021; United Nation Children's Fund, 2020). 
In the other side, the government's regulations in controlling the spreading of Coronavirus 2 or COVID-19 such as lockdown had enforced the children to stay at home altogether with the adults in the family, without regular access to professionals' sets up perfect conditions for a safeguarding failure and to put them into risk. Some social workers had to quarantine themselves in order to overwhelm the security team and make it difficult to provide services (Green, 2020). Thus, Risk Communication and Community Engagement (RCCE) is important as the response to reduce the uncertainty and to support the sustainability of Child Protection Program (CRP) during pandemic COVID-19 (Birungi, Limwame, Rwodzi, \& Koita, 2021).

Moreover, this pandemic affected the children's access to education as the government regulated the online based learning during pandemic (Green, 2020). Central Statistics Bureau (BPS) data of 2020 (2020) reported that one third of 270,20 million people are children. Most of them live in the big cities with various challenges such as poverty and pollution, while those who live in the rural areas have limited access to the basic services such as internet access (United Nation Children's Fund, 2020). These reason becoming the gap for the children who lives in the remote areas in adjusting the system (Green, 2020). Next, Dominelli (2020) stated that it is difficult to social workers to give services during the pandemic as it is risky and challenging. Santoso (2021) said that ALIT Indonesia needs the local volunteer to help the organization reached their target group, such as assisted children and their family with a strict health protocols as the risk reduction mitigation for the organization sustainability of the program during the pandemic COVID-19.

A pandemic as a part of crisis situation of health that influences a massive wide variety of humans which can overwhelm the national health system's ability to manage it (Dominelli, 2020). In a crisis situation, communication and information is one of the potentials for risk management when the community can understand the impact of an activity. Public relations must provide information anytime as a result of media scrutiny during the crisis situation (Kriyantono, 2019).

Risk communication management helps a person prepare steps that can be used to minimize activity risks (Dharmawan, 2020). Moreover, from an online interview through zoom with Wacana, the chairperson for the Alliance for Indonesia Child Violation Reduction (PKTA) said that the Civil Society Organization (CSO) at least had program risk mitigation for the children. During pandemic, it is reported that the children risk of digital world are increased due to less of supervision of the adult and low of digital literacy. Thus, it is important for an organization to have risk assessment and mitigation on its program implementation.

Some of the facts above confirm that the COVID-19 pandemic has had many impacts on various sectors, one of which is the crisis of child rights protection programs. Therefore, this research is important to do in order to know the risk communication strategy in the implementation of the child rights protection program. The crisis progressed quickly to an imminent status when public knowledge and disputes tended to be blamed on companies, including geologists, mass media, NGOs, victims and the government (Kriyantono, 2012). 
Then this study will look at the roles that Civil Society Organizations (CSOs) or Non-Governmental Organizations (NGOs) can play in overcoming children's problems as part of the pillars of democracy (Arub, Setiyono \& Utomo, 2016). The object of this research is the ALIT Indonesia Foundation as one of the CSOs in Indonesia. One of the program focuses is the Children's Rights Program (CRP) using three core approaches, namely children's participation by prioritizing direct intervention, empowering families and children's environment as part of the community development process, and advocating to encourage policies and changes in people's attitudes that take sides. to child protection (ALIT Indonesia Foundation, 2020)

The approach and guidance carried out by the ALIT Indonesia Foundation to marginalized children such as street children, and children from poor areas both in urban areas and remote areas (hereinafter referred to as assisted children) is to approach in a family manner, act in parallel. with them (friendly) (ALIT Indonesia Foundation, 2020).

The Arek Lintang Foundation (Arek Lintang foundation, hereinafter referred to by its more familiar abbreviation ALIT Surabaya and later transformed into the Indonesian ALIT Foundation) was originally started by several student activists who previously actively studied democratization and humanitarian issues. Activists who are interested in social issues, especially those related to children's rights, tend to be marginalized in the wider discussion of human rights. The need for advocacy for children's rights in Indonesia became more urgent with the collapse of the New Order regime in 1998 which left a prolonged crisis (Liddinillah, 2010)

Liddnillah (2010) in his research found that the condition of street children in the ALIT Surabaya NGO has a unique communication pattern, namely the communication process can occur not only through communication like other children but they can also communicate based on verbal communication symbols (prokem). In addition, street children, with their unique cultural framework, have different forms of communication with other children.

Based on some preliminary research conducted by researchers, it is known that the ALIT Indonesia Foundation has a special risk management and communication strategy in order to obtain effective communication with assisted children, especially in the era of the COVID-19 pandemic. It is important for an NGO or NGO to have a good risk communication strategy, especially in the pandemic era. The researcher assumes that the Indonesian ALIT Foundation can survive during the pandemic because it has a fairly good risk management strategy compared to other NGOs or NGOs. The COVID-19 pandemic has made everyone hindered by the directives of "social distancing". A risk communication strategy is urgently needed by the Indonesian ALIT Foundation in continuing the child rights protection program. This study focuses on knowing the risk communication strategy in the child rights protection program used by the ALIT Indonesia Foundation during the COVID-19 pandemic with a descriptive qualitative research method with a constructivist paradigm. The data collection technique used is in-depth interviews with the main 
stakeholders of the ALIT Indonesia Foundation and the stages of data analysis by Miles, Hubberman, and Saldana.

\section{B. LITERATURE REVIEW}

\section{Crisis Communication in the Pandemic Era}

The development of communication technology increases the potential for an increasingly large crisis (Argenti, 2009). Millar \& Heath (2004) further explained that in a crisis situation in the new media era, we must fight in an information cycle that lasts for 24 hours. Effective action is needed to deal with problems that arise. Companies need to provide a message to convey, because allowing rumors to circulate wildly will only add to the difficulties for the organization. Crisis situations require public relations with communication tools to carry out crisis communication (Kriyantono, 2012). The crisis does not just happen, but is a process of an event (Permata, Wulandari \& Kriyantono, 2020).

According to Akhyar \& Pratiwi (2019), crisis communication is significantly affected by the development of digital technology compared to before the digital era. There are two things that make the difference. First, the communication channel for its distribution. In the pre-digital era, the dissemination of crisis information was only through conventional mass media such as television, radio, and newspapers. There is a pause of several hours for the public to know and react to the crisis. But the crisis in the digital era can spread the information in a matter of minutes. Second, in terms of impact. The impact of the reputation crisis in the digital era is greater than in the predigital era.

\section{Risk Communication Management in the Protection of Children's Rights}

Risk management is part of crisis communication. According to Chase in Kriyantono (2015) states that there must be a fundamental change in the mindset of management in managing issues that require a new approach in the management structure (Jacques, 2008) by adopting a pattern of outside-in thinking, namely organizations need to consider developing issues as information in planning its program of activities.

\section{Risk Communication Strategy}

Risk communication is part of crisis communication and a sub-section of risk management. Risk communication is the real-time exchange of information, advice and opinions between experts and people who face threats to their health, economy or social well-being (Abrams \& Greenhawt, 2020). Risk communication is considered to be an approach to social risk control by relevant agencies with the aim of informing, educating and assisting decision making (Harlina et al., 2018).

The communication strategy is a systematic plan carried out by the ALIT Indonesia Foundation in conducting outreach to the public so that the message conveyed can be received and attracts the attention of the public. Strategy according to Stalk, Evans, \& Shulman (1992) must have an essence in corporate communication, 
namely to weave its main business processes into strategic capabilities that are difficult to imitate and differentiate them from its competitors. "To succeed, a company must weave its key business processes into hard-to-imitate strategic capabilities that distinguish it from its competitors in the eyes of customers".

The risk communication strategy in this case can be interpreted as a systematic plan carried out by the ALIT Indonesia Foundation in conducting outreach to the public so that the messages conveyed can be received and attract the attention of the audience, especially in the risk communication strategy of child rights protection programs in the era of the COVID-19 pandemic.

\section{METHODS}

This study uses a constructivist paradigm, researchers try to find out the construction of informants from the Indonesian ALIT Foundation regarding risk management and communication strategies implemented in the era of the COVID-19 pandemic. The constructivist paradigm according to Kriyantono (2012) is a reality that is relatively in accordance with the relevant specific context assessed by social actors. Researchers in qualitative research play a role in obtaining holistic data that is systematic and integrated (Miles, Huberman \& Saldana, 2013). "Qualitative research tends to be unstructured, the concepts used can be concepts that have not been defined and elaborated strictly" (Hidayat, 2002, p.213). Qualitative research according to Kriyantono (2015) can be used to obtain data by producing more in-depth information. Another reason that researchers use qualitative research is that researchers seek to decipher risk communication strategies used in child rights protection programs during the COVID-19 pandemic.

The object of this research is the Indonesian ALIT Foundation. ALIT is short for Arek Lintang, a Non-Governmental Organization (NGO) which was officially established on April 22, 1999. Many of the founders of ALIT have carried out several assistance tasks for street children in Surabaya since 1996. Data collection in this study is "techniques or methods that can be used by researchers to collect data" (Kriyantono 2014 , p. 95). The research conducted interviews and documentation online through the zoom conference application (on the network). "Technology developments have made in-depth interviews possible not face-to-face, but online: email and by telephone" (Kriyantono, 2012, p. 50).

According to Lichman in (Kriyantono, 2012) explains that the number of informants in qualitative research is easy to change depending on the availability of data in the field. Moreover, informants must be selected based on their capacity in revealing ideas, perceptions, and experiences of the research object (Kriyantono, 2021). Informants in this research were Ananta Lisa Febriyanti as Information and System manager or Public Relations of the Indonesian ALIT Foundation, Rakai Kurmavatara or Slamet Santoso - Program Manager of the ALIT Indonesia Foundation and Sigit Wacono as Chair of the Association for Violence Against Children (PKTA). According to Lichman in (Kriyantono, 2012) explaining that the 
number of informants in qualitative research is easy to change (increase and decrease) depending on the availability of data in the field.

Data collection methods used are interviews and documentation. Interview is a technique of collecting data by conducting questions and answers directly to the informant. The question and answer was carried out by two parties, namely the interviewer (interviewer) who asked the question and the interviewer (interviewer) who provided the answer to the question (Moleong, 2012). The assessment of the validity of qualitative research usually occurs during the process of data collection and analysis of data interpretation (Kriyantono, 2006).

\section{RESULTS AND DISCUSSION}

\section{Social Media as a Risk Communication Strategy for ALIT Indonesia}

Social media is now a vehicle for disseminating information, education, and entertainment by the public to the public. In the midst of the COVID-19 pandemic, which requires people to practice social distancing and lockdown, they are increasingly turning to social media for support, entertainment, and staying connected with others (Grover, Cheung, Thatcher, 2020).

The results show that the ALIT Indonesia Foundation tends to choose several social media to be used as a vehicle for disseminating information and education, namely Instagram, Facebook, YouTube and Zoom conference. Social media is considered as one of the risk communication strategies used by the ALIT Indonesia Foundation.

The results showed that risk communication conveyed through YouTube, Instagram or Facebook content of the ALIT Indonesia Foundation received positive and interactive reactions from netizens. Through learning videos, the ALIT Indonesia Foundation tries to provide education to parents in the form of content produced in the form of infographics with informative and educational messages. Educational messages containing parenting at home during the COVID-19 pandemic, appeals for health protocols, and other information. This study shows that risk communication will be effectively delivered through Instagram and Facebook by using educational content.

The use of social media in running ALIT Indonesia Foundation programs aims to facilitate access to information and also reach assisted children who are far apart. The use of social media and new media by the Indonesian ALIT Foundation in the COVID-19 pandemic crisis has been quite good. The ALIT Indonesia Foundation uses Facebook and Instagram to immediately convey information. The information is also consistent with what is stated in the statement on the official website. When the information has been delivered immediately, the audience will not be confused and can make decisions because they have been educated with the educational content created by the ALIT Indonesia Foundation.

Social media plays a significant role during the pandemic as it allows people to share news and personal experiences and viewpoints with each other in real-time and globally (Islam et al., 2020). Beside that, conducting a good media relations activity 
should be performed by PR practitioners (Syahri, Kriyantono \& Nasution, 2015). In this case, Yayasan ALIT Indonesia according to Excellence theory of James Grunig, Yayasan ALIT Indonesia need to always kept ethical dimension in doing their roles, and it also happened to those who conducted media relations for example with public and field staff.

The use of social media as a risk communication strategy for the Indonesian ALIT Foundation is considered quite effective. Information \& System Manager or Public Relations of the ALIT Indonesia Foundation, Icha said that the ALIT Indonesia Foundation utilizes social media Facebook and Instagram as the main media (Febriyanti, AL personal communication via zoom, 12 June 2021). This is reinforced by data from Hootsuite (2020) which states that active users of social media in Indonesia reach $59 \%$ of the total world population, and specifically for Instagram users, Indonesia is the fourth largest country in the world with the highest user age in the 18-34 range. year. The main purpose of the ALIT Indonesia Foundation using social media is to be able to communicate with assisted children. More than that,

The importance of using social media as a risk communication tool is also conveyed by (Abrams \& Greenhawt, 2020) in their research which explains that social media is a potential way to ensure that risk communication runs properly, because the public relies heavily on media and social relationships to inform the level of risk perception. they.

There are several benefits of using social media as a risk communication strategy by the ALIT Indonesia Foundation. First, the resolution of the crisis on social media can be analyzed from who the stakeholders (stakeholders) involved in the crisis are. In terms of handling risk communication from the COVID-19 pandemic crisis, it is known in the Situational Crisis Communication Theory (SCCT) theory that it can be used to discuss crisis communication that occurs on social media. From the pandemic case, the type of victim crisis, which is the type of crisis where the organization becomes the victim of the crisis, namely COVID-19.

Second, social media is used as a risk communication strategy because of the COVID-19 crisis that must be addressed immediately because it has a large viral potential that can be fatal because it threatens the good reputation of the organization. In this case, the selection of social media by ALIT Indonesia is quite appropriate. By uploading content as well as education via zoom conference, victims of sexual violence can access it easily and for free. It is hoped that through this medium, the situation can be handled properly in less than 24 hours.

Third, although the COVID-19 crisis has gone viral on social media, crisis responses can be carried out not only online but also offline. In the case of the Indonesian ALIT Foundation, sexual violence is often found starting from social media such as children exposed to pornography and eventually getting violence from colleagues or their environment. Through this platform, social media as a risk communication strategy works with victims and parents so they can get education so that incidents like this don't happen. 
Fourth, in a large-scale crisis involving strong social issues such as COVID-19, the presence of the government or the company's highest leadership in the strategy of responding and explaining directly to the public has a significant impact on crisis recovery. This is because the public's decline in the highest leadership of the company directly shows the company's commitment and seriousness to overcome the crisis that occurred to the end. In this case, ALIT Indonesia's risk communication strategy is often the Manager or Program Manager of ALIT Indonesia who intervenes to create educational content and becomes a speaker in a zoom conference to improve the situation.

Problems on social media are also one of the reasons for the increase in cases of violence against children. The ALIT Indonesia Foundation and PKTA as NGO institutions related to the protection of children's rights explained that in the era of the COVID-19 pandemic, internet use increased because people were prohibited from leaving their homes. The problem arises because there are more and more frauds and incidents related to child rights abuse through social media. The ALIT Indonesia Foundation as part of the PKTA explained that there were stages of induction, briefing, providing education to each NGO member to conduct socialization not to contact unknown people in order to avoid unwanted things (Wacono, S., personal communication via zoom, 1 October 2021).

Although the increased use of the internet increases the mitigation of the risk of violence or child abuse on social media, on the other hand, social media is also very useful for conveying program messages. The difficulty that arises is when the PKTA Alliance cannot reach education for children in the East because of the signal obstruction (Wacono, S., personal communication via zoom, October 1, 2021).

Other problems related to social media and children's rights arise when children under the age of gadget literacy are not able to manage gadgets properly. The negative impact that arises is that children use gadgets without rules and are vulnerable to being exposed to pornography. Cases of sexual violence against children have now reached 89 cases in 2021, the main cause of which is exposure to pornography from the use of mobile phones and social media (Wacono, S., personal communication via zoom, October 1, 2021).

It is important for the ALIT Indonesia Foundation to use social media to connect volunteers or assisted children. The ALIT Indonesia Foundation already has up to 3000 assisted children spread across East Java, NTT and Bali. The presence of social media is very important for the ALIT Indonesia Foundation. In addition to Instagram and Facebook social media, the ALIT Indonesia Foundation also utilizes YouTube media and zoom conferences as risk communication strategies in the pandemic era.

During the COVID-19 pandemic, the Indonesian ALIT Foundation program must continue. The ALIT Indonesia Foundation has unique characteristics as an NGO. In the pandemic era, the ALIT Indonesia Foundation has three divisions, namely advocacy, communication development and management information system. The COVID-19 safety program is under development communication. The Social Safety 
Network program during COVID-19 is a social security network during the pandemic (Santoso, S., personal communication via zoom, 18 February 2021). The purpose of the social network program during COVID-19 is to form a network and ensure the health of the assisted children so that no one is exposed to COVID-19. This is in accordance with the statement of Kriyantono (2012) which says that the public is important and organizations need to pay attention to the needs and interests of the public.

One of the risk communication strategies carried out by the Indonesian ALIT Foundation since the COVID-19 pandemic is the creation of a mentoring program to learn to pursue school materials or determine certain themes and make educational videos for parents to raise children in the era of the COVID-19 pandemic. The ALIT Indonesia Foundation provides a schedule for assisted children, such as Monday discussing tests related, Tuesday heading to improving life skills or handicrafts, Wednesday providing gardening activities and so on. If it is constrained by social distancing, Slamet said, the program can be run online for areas that allow internet signals (Santoso, S., personal communication via zoom, 18 February 2021).

When the COVID-19 pandemic came, the Indonesian ALIT Foundation program still had to run and could not work from home (WFH). There are several things that the ALIT Indonesia Foundation has done in this regard, including tightening the Health protocol from the volunteer level to the director. One of the main strategies used is to use WhatsApp, Instagram and YouTube communication media to maximize coordination (Santoso, S., personal communication via zoom, 18 February 2021).

Risk communication is often used in the business world, but in this case risk communication is used in the Indonesian ALIT NGO as a risk communication strategy. In order to develop a communication strategy, thinking is needed by taking into account the supporting and inhibiting factors (Effendy, 2007).

One of the ongoing communication programs is the Project Against Commercial Sexual Exploitation of Children in the Tourism Sector (SECTT). The program in the second year is referred to as the DEWA DEWI RAMADAYA program. The main objective of this program is to realize SDG's that children can enjoy a better life by getting adequate nutrition, education and equal access to public services in a good family environment and a biological environment that is safe from disasters. Risk communication is carried out by making a roadmap related to the project against commercial sexual exploitation of children in the tourism sector.

Based on the relationship between interview data and theories related to social media analysis, it can be concluded that social media has an important role in risk communication at the Indonesian ALIT Foundation. Social media is used as a liaison between assisted children and field staff or volunteers. Moreover, social media is used as a means of product distribution, namely material via Zoom, YouTube, Facebook, Instagram, or the official website of the Indonesian ALIT Foundation. Social media really helps the performance of volunteers to evaluate. Moreover, social media also provides space for volunteers and field staff to continue to provide good material to assisted children in the era of the COVID-19 pandemic. 


\section{Product Development as a Risk Communication Medium}

In crisis communication, companies or organizations are now not only answering questions from the mass media, but also answering questions from the public. In this case, the ALIT Indonesia Foundation uses various products as a medium of risk communication during the pandemic, such as posters, educational videos, and also books related to the protection of children's rights. Social media like Facebook and Instagram make it possible to reach the public directly. If this is used optimally, it can have a positive impact on companies or organizations to reduce problems related to the protection of children's rights.

Making a product as a risk communication medium during this pandemic is very useful for distributing information, because the organization or company can convey messages according to their own version, can be understood better and packaged much more educatively for children or parents in protecting children's rights. Before there were official websites and social media, companies or organizations could only answer through the media. This greatly facilitates access for anyone to be open and consult related to cases of protecting children's rights.

Before the COVID-19 pandemic came, the Indonesian ALIT Foundation as a national NGO engaged in the field of child protection was accustomed to conducting live or offline events. The difference is, since COVID-19 arrived in Indonesia, the ALIT Foundation has tried to run a risk communication program by creating risk mitigation products. The child rights protection program carried out by the ALIT Indonesia Foundation, especially in the era of the COVID-19 pandemic, seeks to directly assist children in the pandemic era. The social network program is one of the programs carried out by complying with the Health protocol and helping the assisted children fulfill the medical equipment.

Based on the informant's narrative, it is known that the ALIT Indonesia Foundation produces several products as a risk communication strategy in the era of the COVID-19 pandemic, including the production of books, educational videos, as well as provision of product manufacture such as hand sanitizer for assisted children. The purpose of these activities is to reduce the negative impact of the pandemic.

Based on the results of an interview with the Program Manager of the Indonesian ALIT Foundation, Slamet Santoso, it is known that there are 6 programs of the Indonesian ALIT Foundation related to the protection of children's rights. The 6 programs include social safety during COVID-19, self-help gods, children's rights programs, youth development programs, and organizational development programs (Santoso, S., personal communication via zoom, 18 February 2021).

The 6 programs are realized in the form of books, or educational videos that are distributed and intended for assisted children from various regions. For example, the social network program is one of the programs carried out by complying with health protocols and helping assisted children fulfil health equipment. Furthermore, the ALIT Indonesia Foundation also accompanied the children and distributed hand sanitizer and ensured that the children's nutrition was in good condition (Santoso, S., personal communication via zoom, 18 February 2021). 
The ALIT Indonesia Foundation is part of the PKTA Alliance (Alliance for the Elimination of Violence Against Children). The function of the ALIT Indonesia Foundation to join the PKTA Alliance is to become a government partner. More than that, the Indonesian ALIT Foundation can be a benchmark for the government to formulate a roadmap in the PKTA strategic plan for 2021-2025. This is also related to increasing resource persons or facilitators in overseeing the PKS Bill and making policies (Wacono, S., personal communication via zoom, October 1, 2021). The PKTA Alliance aims to help the government statement to make action. Chairman of PKTA Sigit Wacono explained that PKTA helped the government a lot in handling cases. Often if the government is late in moving, PKTA, including ALIT Indonesia, moves forward earlier to assist in cases of protecting children's rights.

In carrying out the safety network program during COVID-19 the ALIT Indonesia Foundation has 1 volunteer whose aim is to hold 10 assisted children. Everyone can register via the online application to become a volunteer with the fieldstaff system. At the time of evaluation, volunteers will recite things according to the teaching module. At the beginning of being a volunteer, the main thing taught is PERLINA or the Protection of Children's Rights. PERLINA is a child rights protection module that contains 10 chapters on the implementation and conventions of children's rights. Each volunteer in their assistance will be supervised by field staff and conduct an evaluation once a week. Each assisted child must attach information whether he has parents or has moved to foster care (Santoso, S., personal communication via zoom, 18 February 2021)

The ALIT Indonesia Foundation, according to Program Manager Slamet Santoso, has its own system related to outreach to assisted children. For example, each field-staff can reach all of the assisted children whose houses are close together. But the case will be very different when it is in the Bromo field staff, for example, each child has a location range of up to $1-2 \mathrm{~km}$ so that sometimes only a few children can be reached from one area. (Santoso, S., personal communication via zoom, 18 February 2021)

The risk communication strategy in the child rights protection program carried out by the ALIT Indonesia Foundation includes direct assistance to assisted children even though they are affected by Covid. Although most schools have to go online, in some places where the signal is not reached, ALIT Indonesia volunteers continue to teach and assist children to keep learning. Of course, this is very concerned about health protocols. Making products as a medium of communication is needed to maintain organizational stability. The ALIT Indonesia Foundation can continue to run its program through products as the intended communication medium.

\section{E. CONCLUSION}

Based on the research results, the risk communication strategy used by the ALIT Indonesia Foundation in carrying out the Project against Commercial Sexual Exploitation of Children in the Tourism Sector (SECTT), the Social Safety Network program during COVID-19 and the DEWA-DEWI RAMADAYA program have 
helped children assisted by the ALIT Indonesia Foundation to keep getting physical and mental encouragement to face the pandemic situation.

The organization has carried out mentoring activities for assisted children or called "Arek Lintang" by volunteers or field staff through critical education through discussions, training, advocacy and campaigns. The risk communication carried out resulted in a roadmap related to the project against commercial sexual exploitation of children in the tourism sector. The risk communication strategy carried out by the ALIT Indonesia Foundation is very helpful for government programs to carry out crisis management and risk management due to the COVID-19 pandemic.

Risk communication is planned and distributed through social media Facebook, YouTube, Instagram, and Zoom conference. In addition, the ALIT Indonesia Foundation makes risk communication products in the form of videos, posters, and books as a medium for risk communication strategies for child rights protection programs in the COVID-19 pandemic era.

Subsequent research could replicate the case of the pandemic crisis with other NGOs on issues that can be debated globally. The results of the study reveal that most of the NGO risk communication strategies at the national level in this case are only specifically in Indonesia and have not described the strategies used to develop relationships with international stakeholders in the COVID-19 pandemic. Further research is needed to address this issue, using the findings from this study as a starting point. Further research can conduct research related to risk communication strategies in Non-Governmental Organizations or NGOs with a different focus in the study of crisis communication, risk management, or risk communication.

\section{REFERENCES}

1. Abrams, EM, \& Greenhawt, M. (2020). Risk communication during COVID-19. The Journal of Allergy and Clinical Immunology in Practice, 8(6), 1791-1794.

2. Akhyar, D., \& Pratiwi, AS (2019). Social media and crisis communication. Ultimacomm: Journal of Communication Studies, 11(1), 35-52.

3. Argenti, P. A. (2009). Corporate communications. New York: McGraw Hill.

4. Arub, S. S., Setiyono, B., \& Utomo, S. (2016). The role of non-governmental organizations in the handling and protection of children of Indonesian migrant workers (case study of child care homes for Indonesian workers). Journal of Politics and Government Studies, 5(2), 241-250.

5. Bhukuth, A., \& Ballet, J. (2015). Children of the street: Why are they in the street? How do they live?. Economics $\mathcal{E}$ Sociology, 8(4), 134.

6. Birungi, A., Limwame, K., Rwodzi, D., \& Koita, Y. (2021). A risk communication and community engagement (RCCE) response to support maternal, infant and young child nutrition in the context of COVID-19 in Rwanda. Field Exchange 65, 46.

7. Dharmawan, H. C. B. (2020). Disaster risk reduction communication strategy by BNPB via Instagram @bnpb_indonesia (Doctoral dissertation, Universitas Pelita Harapan). 
8. Dominelli, L. (2020). Surviving Covid-19: Social work issues in a global pandemic (Child Protection and welfare, and society care). Stirling: Stirling University.

9. Dutta, D., \& Hazarika, B. (2020). COVID-19 pandemic and violation of child rights. European Journal of Molecular \& Clinical Medicine, 7(8), 2115-2118.

10. Effendy, O. S. (2007). Communication science theory and practice. Bandung: Rosdakarya Teenagers.

11. Eleanora, F. N., \& Sari, A. (2019). Role and function of Indonesian child protection commission in providing against victims of violence in the street. Prasada Journal of Law, 6(2), 103-108.

12. Green, P. (2020). Risks to children and young people during the COVID-19 pandemic. $B M J, \mathrm{~m} 1669$.

13. Harlina, R., Fatimah, S., \& Setiawan, I. (2018). Analysis of Risk Communication Network for Shallot Farmers: A Case Study of Rindu Alam Farmer's Group in Cikawao Village, West Java Province. Journal of Agrisep, 17(21), 197-206.

14. Islam, A. K. M. N., Laato, S., Talukder, S., \& Sutinen, E. (2020). Misinformation sharing and social media fatigue during COVID-19: An affordance and cognitive load perspective. Technological Forecasting and Social Change, 159(May), 120201.

15. Kendedes, I. (2020). Violation against children during pandemic covid-19. Journal of Harkat: Gender Communication Media, 16(1), 66-76.

16. National Commission of Violence against Women. (2021). Women in the grip of a pandemic: Spike in sexual violence, cyber violence, child marriage, and limited handling amidst COVID-19. CATAHU 2021: Annual Record of Violence Against Women 2020.

17. Indonesian Child Protection Commission. (2014). Map of child protection problems in Indonesia. Retrieved from: https://www.kpai.go.id/publikasi/article/petaperjualan-perlindungan-anak-di-Indonesia.

18. Kriyantono, R. (2006). Teknik praktis riset komunikasi kuantitatif dan kualitatif disertai contoh praktis skripsi, tesis, dan disertasi riset media, public relations, advertising, komunikasi organisasi, komunikasi pemasaran. Jakarta: Kencana.

19. Kriyantono, R. (2012). Public Relations Writing. Teknik Produksi Media Public Relations dan Publisitas Korporat. Jakarta: Kencana Prenada Media Grup.

20. Kriyantono, R. (2012). Measuring a company reputation in a crisis situation: An ethnography approach on the situational crisis communication theory. International Journal of Business and Social Science, 3(9).

21. Kriyantono, R. (2021). Teknik praktis riset komunikasi kuantitatif dan kualitatif. Disertai contoh praktis skripsi, tesis, dan disertasi riset media, public relations, advertising, komunikasi organisasi, komunikasi pemasaran (2 ${ }^{\text {nd }}$ ed.). Jakarta: Kencana Prenada Media Group.

22. Kriyantono, R. (2012). The situational theory of the publics in an ethnography research: Identifying public response to crisis management. International Journal of Business and Social Science, 3(20).

23. Kriyantono, R. (2014). Teori Public Relations Perspektif Barat dan Lokal: Aplikasi Penelitian dan Praktik. Jakarta: Kencana Prenada Media Group 
24. Kriyantono, R. (2014). Local \& Western synergy in communication theory and practice. In the call for Paper Conference on Media, Communication, and Sociology (COMICOS) 2014: "Bridging the gap: Synergy, Connection, and Convergence. Yogyakarta, Indonesia: Atmajaya University Yogyakarta.

25. Syahri, M. A., Kriyantono, R., \& Nasution, Z. (2015). An explanative study on the different perceptions of journalists toward media relations of governmental and private public relations. Asian Journal of Humanities and Social Sciences, 3(1), 36-48.

26. Kriyantono, R. (2015). Public relations, issue \& crisis management: Critical Public relations approach, Critical and Qualitative Ethnography. Jakarta: Kencana Prenada Media Group

27. Kriyantono, R. (2019). Apologia strategies and ethical aspects of government public relations in a crisis situation. Jurnal Representamen, 5(2).

28. Liddinillah, F. (2010). Communication patterns of street children: Ethnographic study of Communication at the Non-Governmental Organization Arek Lintang Surabaya (Undergraduate thesis, IAIN Sunan Ampel Surabaya).

29. Permata, A. A. C., Wulandari, M. P., \& Kriyantono, R. (2020). Crisis Management of Brawijaya University. International Journal of Science and Society, 2(2), 187-202.

30. Reading, R., Bissell, S., Goldhagen, J., Harwin, J., Masson, J., Moynihan, S., ... \& Webb, E. (2009). Promotion of children's rights and prevention of child maltreatment. The Lancet, 373(9660), 332-343.

31. Stalk, G., Evans, P., \& Shulman, LE (1992). Competing on capabilities: The new rules of corporate strategy. Harvard business review, 70(2), 57-69.

32. SS Teo, S., \& Griffiths, G. (2020). Child protection in the time of COVID-19. Journal of pediatrics and child health, 56(6), 838-840.

33. United Nations Children's Fund (2020). The state of children in Indonesia - Trends, opportunities and challenges for realizing Children's Rights. Jakarta: UNICEF Indonesia. 